\title{
Aggressive natural killer cell leukemia: a case report
}

This article was published in the following Dove Press journal: International Medical Case Reports Journal

\section{Ying $\mathrm{Hu}$ jingbo Wang}

Department of Hematology, Aerospace Center Hospital, Beijing, People's Republic of China
Correspondence: Jingbo Wang Department of Hematology, Aerospace Center Hospital, Yuquan Road, Haidian District, Beijing 100049, People's Republic of China Tel +86 1059971216

Email dpwangjingbo@sina.com
Abstract: Aggressive natural killer (NK) cell leukemia is a rare hematological malignancy. It often presents with a rapidly declining clinical course and a poor prognosis with a median survival of a few months. We report the case of a 23-year-old man with high fever, enlarged lymph nodes, splenomegaly, cytopenia, liver dysfunctions, coagulation disorders and hemophagocytosis. Computed tomography scan showed right lung shadow. Lung involvement was considered. Histological examination of the lung was not performed because of low platelets and coagulation disorders. Bronchoscopic examination revealed positive Epstein-Barr virus in bronchoalveolar lavage fluid. Bone marrow and lymph node phenotype showed CD56+ CD3- NK cells type. He died of respiratory failure a week after diagnosis.

Keywords: hemophagocytosis, Epstein-Barr virus, CD56+CD3-NK cells, aggressive natural killer cell leukemia

\section{Introduction}

Diseases originating from mature natural killer (NK) cells include extranodal NK/T-cell lymphoma-nasal type, aggressive natural killer cell leukemia (ANKL) and chronic lymphoproliferative disorders of NK cells. ${ }^{1}$ ANKL is the rarest and worst malignancy. ANKL is an Epstein-Barr virus (EBV)-associated tumor most prevalent among Asian young adults (median age of 42 years). ${ }^{2}$ There is no standard treatment currently available for patients.

\section{Case presentation}

A 23-year-old man with no prior medical history was admitted to the Department of Respiratory Medicine. The symptoms were fever for 1 month and a weight loss of $5 \mathrm{~kg}$ in the last 1 month. Physical examination revealed enlarged spleen and lymph nodes. The blood cell counts were as follows: leukocyte (white blood cell [WBC] $5.2 \times 10^{9} / \mathrm{L}$, neutrophilic granulocyte (NEU) 44.4\%, lymphocyte (LYM) 49\%, hemoglobin (HGB) 128 $\mathrm{g} / \mathrm{L}$, platelet $159 \times 10^{9} / \mathrm{L}$. Biochemistry showed marked increased level of lactate dehydrogenase to $551.6 \mathrm{U} / \mathrm{L}$, alanine transaminase to $577.2 \mathrm{U} / \mathrm{L}$, direct bilirubin to $64.3 \mathrm{umol} / \mathrm{L}$, and indirect bilirubin to $30.7 \mathrm{umol} / \mathrm{L}$. Examinations also revealed the following levels: albumin $31.2 \mathrm{~g} / \mathrm{L}$, serum creatinine $59 \mathrm{umol} / \mathrm{L}$, triglyceride $2.06 \mathrm{mmol} / \mathrm{L}$, ferritin $>1500$ $\mathrm{ng} / \mathrm{mL}, \beta 2$-microglobulin $5.68 \mathrm{mg} / \mathrm{L}$, erythrocyte sedimentation rate $10 \mathrm{~mm} / \mathrm{h}, \mathrm{C}$-reactive protein $5 \mathrm{mg} / \mathrm{L}$, prothrombin time $12.4 \mathrm{~s}$, prothrombin activity $82 \%$, international normalized ratio 1.13, partial thromboplastin time $45.9 \mathrm{~s}$, and fibrinogen $2.18 \mathrm{~g} / \mathrm{L}$.

Serum detection revealed positive EBV $\operatorname{lgG}$ and negative $\operatorname{lgM}$. Computed tomography (CT) scan showed no neoplasm in the nasal cavity and oropharynx. 
CT scan showed right lung large lesions, partial pleural effusion, splenomegaly and mild hepatomegaly. Bronchoscopic examination revealed positive EBV in bronchoalveolar lavage fluid.

Fifteen days after hospitalization, the following were found: WBC $2.3 \times 10^{9} / \mathrm{L}$, HGB $110 \mathrm{~g} / \mathrm{L}$, PLT $24 \times 10^{9} / \mathrm{L}$, NEU $28 \%$, LYM 47\%, abnormal cells $25 \%$ in peripheral blood. A hematological neoplasm was suspected. Bone marrow smears showed $10 \%$ abnormal cells with varying size, irregular shape, dark blue cytoplasm, azurophilic granules and some hemophagocytes. Bone marrow flow cytometry showed the following phenotype: CD56+, CD2+, CD8dim+, CD159a+, CD94bri+, CD16+ (partially), CD161+(partially), KI-67(15\%), CD4-, CD3-, CD5-, CD30-, CD158a/h-, CD158b-, CD159c-, TCR-ab-, TCR-rd-, CD117-, CD57-. Bone marrow biopsy showed clustered abnormal cells. Lymph node biopsy immunohistochemistry showed CD56+, CD2+, CD8dim+, CD94bri+, CD161+, CD16+, CD159a+ (partially), CD7+ (partially), CD4-, CD3-, CD5-, CD159c-, TCR-, $\lg \mathrm{H}-$. A diagnosis of ANKL was made. Only glucocorticoid was given. Other chemotherapy drugs were not administered because the patient did not agree. The patient sustained high fever and presented with dyspnea and nasal bleeding. A week after diagnosis, the patient died of respiratory failure.

The patient's next of kin provided written informed consent to publish this case report.

\section{Discussion}

ANKL is recognized by the WHO classification as a distinct neoplasm that constitutes approximately $10 \%$ of all large granular lymphocyte (LGL) lymphoproliferative disorders. ${ }^{3}$ ANKL occurs in younger adults and is more common in males. Presentations usually have fever, B symptoms, jaundice, lymphadenopathy, hepatosplenomegaly, circulating leukemic cells and cytopenia, disseminated intravascular coagulation, hemophagocytic syndrome and liver dysfunction. Morphologically, mature NK cells are large granular lymphoid cells, which are characterized by the presence of pale cytoplasm containing azurophilic granules. Unlike T-cell large granular lymphocytes, they are negative for CD3. Furthermore, clonal rearrangement of the T-cell receptor (TCR) gene is also absent in NK cells. ANKL was diagnosed in our case based on clinical manifestations and LGL with positive CD56, CD16 and negative CD3, CD4, CD5, CD57, TCR. T-cell LGL leukemic cells typically co-express $\mathrm{CD} 3+, \mathrm{CD} 8+$ and CD57+ markers and hence were excluded. CT scan showed no mass in nasal cavity and oropharynx, and so NK/T cell lymphoma-nasal type was also excluded. Flow cytometric immunophenotyping is a primary laboratory tool for the accurate identification of NK cells, which are expressed by cells such as CD2, CD7, CD16 and CD56, and antigens, which are not expressed by cells such as sCD3 and CD5. ${ }^{4}$ Flow cytometric immunophenotyping studies for ANKL revealed that all cases have bright CD56 expression and lack CD57 expression. The vast majority of cases do not express CD16 or CD8; some cases are CD16 positive. ${ }^{5}$ Standard therapies such as CHOP (cyclophosphamide, doxorubicin, vincristine and prednisone) are ineffective when used to treat ANKL. ${ }^{6}$ Intensive acute lymphocytic leukemia-like therapies with central nervous system prophylaxis should be considered as an initial treatment for ANKL. Consolidation therapy with hematopoietic cell transplantation should also be considered for those patients achieving responses to induction therapy. ${ }^{7}$ A multicentric study of 15 patients with relapsed, refractory or disseminated extranodal NK/T-cell lymphoma, nasal type and ANKL treated with L-asparaginase-containing regimens showed that seven patients reached complete remission and only two relapsed. L-asparaginase-based regimen should be considered as a salvage treatment, especially for patients with disseminated disease. ${ }^{8}$ SMILE protocol (dexamethasone, methotrexate, ifosfamide, L-asparaginase, etoposide) achieved $67 \%$ response and $50 \%$ complete response. ${ }^{9}$

\section{Disclosure}

The authors report no conflicts of interest in this work.

\section{References}

1. Dearden CE, Johnson R, Pettengell R, et al; British Committee for Standards in Haematology. Guidelines for the management of mature T-cell and NK-cell neoplasms (excluding cutaneous T-cell lymphoma). Br J Haematol. 2011;153(4):451-485.

2. Suzuki R, Suzumiya S, Nakamura S, et al; NK-cell Tumor Study Group. Aggressive natural killer-cell leukemia revisited: large granular lymphocyte leukemia of cytotoxic NK cells. Leukemia. 2004;18(4):763-770.

3. Lamy T, Loughran TP Jr. Clinical features of large granular lymphocyte leukemia. Semin Hematol. 2003;40(3):185-195.

4. Li C, Tian Y, Wang J, et al. Abnormal immunophenotype provides a key diagnostic marker: a report of 29 cases of de novo aggressive natural killer cell leukemia. Transl Res. 2014;163(6):565-577.

5. Lima M, Spínola A, Fonseca S, et al. Aggressive mature natural killer cell neoplasms: report on a series of 12 European patients with emphasis on flow cytometry based immunophenotype and DNA content of neoplastic natural killer cells. Leuk Lymphoma. 2014;56(1):103-112.

6. Ruskova A, Thula R, Chan G. Aggressive natural killer-cell leukemia: report of five cases and review of the literature. Leuk Lymphoma. 2004;45(12):2427-2438.

7. Okamura T, Kishimoto T, Inoue M, et al. Unrelated bone marrow transplantation for Epstein-Barr virus-associated T/NK-cell lymphoproliferative disease. Bone Marrow Transplant. 2003;31(2):105-111.

8. Jaccard A, Petit B, Girault S. L-Asparaginase-based treatment of 15 western patients with extranodal NK/T-cell lymphoma and leukemia and a review of the literature. Ann Oncol. 2009;20(1):110-116.

9. Yamaguchi M, Suzuki R, Kwong YL, et al. Phase I study of dexamethasone, methotrexate, ifosfamide, 1-asparaginase, and etoposide (SMILE) chemotherapy for advanced-stage, relapsed or refractory extranodal natural killer (NK)/T-cell lymphoma and leukemia. Cancer Sci. 2008;99(5):1016-1020. 
International Medical Case Reports Journal

The International Medical Case Reports Journal is an international, peer-reviewed open-access journal publishing original case reports from all medical specialties. Previously unpublished medical posters are also accepted relating to any area of clinical or preclinical science. Submissions should not normally exceed 2,000 words or
4 published pages including figures, diagrams and references. The manuscript management system is completely online and includes a very quick and fair peer-review system, which is all easy to use. Visit $\mathrm{http}: / /$ www.dovepress.com/testimonials.php to read real quotes from published authors.

Submit your manuscript here: https://www.dovepress.com/international-medical-case-reports-journal-journal 